\title{
Eksploitasi dan Kekuasaan: Studi Kasus Penggunaan Sumberdaya Lahan di Desa Kampala Kabupaten Jeneponto
}

\author{
Eksploitation and Power: Use Case Studies of Land Resources in Village Kampala \\ Jeneponto District
}

\author{
Alima Bachtiar Abdullahi ${ }^{*}$, Nurman Ali Saiful), Saleh S. Ali ${ }^{3}$, Eymal Demmallino ${ }^{3}$, \\ Rahmadanih $^{3}$ \\ 1) Politeknik Pertanian Negeri Pangkajene dan Kepulauan \\ 2) Mahasiswa Program Doktor IImu Pertanian Minat Sosial Ekonomi UNHAS \\ 3,) Fakultas Pertanian Universitas Hasanuddin \\ *Corresponding author: alima agro.politanipangkep@yahoo.com
}

Diterima tanggal 16 Maret 2020, Disetujui tanggal 03 April 2020

\begin{abstract}
Abstrak
Pola hubungan masyarakat Jeneponto adalah pola hubungan pinggawa-sawi. Pinggawa adalah penguasa sumberdaya (Karaeng) dan sawi adalah orang yang tidak memiliki sumberdaya kecuali dirinya sendiri. Kajian ini bertujuan untuk mengetahui bagaimana relasi sosial dalam struktur masyarakat lokal, serta untuk mengetahui sejauh mana struktur sosial tersebut mencerminkan adanya ekspoitasi kekuasaan pinggawa kepada sawinya. Kajian ini dilaksanakan pada bulan Mei-Juli 2017 di Desa Kampala Kecamatan Arungkeke Kabupaten Jeneponto.Menggunakan pendekatan kualitatif dengan strategi studi kasus. Pemilihan lokasi dilakukan purposive sampling.Teknik pengumpulan data menggunakan indepth interview diawali dengan Focuss Group Discussion didukung dengan observasi, data yang diperoleh dari instansi terkait, laporan penelitian, literatur, jurnal maupun karya ilmiah lainnya.Data divalidasi dengan teknik triangulasi, kemudian data dianalisis dengan sistematis. Hasil penelitian menunjukkan bahwa relasi sosial antara pinggawa dan sawi di Desa Kampala adalah memiliki hubungan dekat secara emosional dan memiliki hubungan yang saling membutuhkan (ada ketergantungan) dalam kehidupan sosial budayanya. Struktur sosial tertinggi di Desa Kampala adalah Karaeng atau mereka yang memiliki garis keturunan kerajaan yang menjadi pemegang kekuasaan dan pengambil kebijakan. Ekspolitasi yang terjadi antara pinggawa dan sawi tidak dalam bentuk materi, akan tetapi dalam bentuk penggunaan kekuasaan oleh Karaeng yang dilakukan untuk tujuan popularitas, status maupun kepentingan politik kepada masyarakat pengguna lahan Karaeng (masyarakat wajib mengikuti semua yang diarahkan oleh Karaeng).
\end{abstract}

Kata kunci: eksploitasi, kekuasaan, sumberdaya lahan, pinggawa-sawi

\section{Abstract}

The pattern of Jeneponto community relations is the pattern of pinggawa-sawi relationships. Pinggawa is the master of resources (Karaeng) and mustard is a person who has no resources except himself. This study aims to find out how social relations in the structure of local communities, as well as to find out the extent to which the social structure reflects the exploitation of the power of the people to the bride. This study was conducted in May-July 2017 in Kampala Village, Arungkeke sdb-District, Jeneponto district.Using a qualitative approach to case study strategies. The location selection was purposive sampling. Data collection techniques using independent interviews beginning with Focuss Group Discussion supported by observation, data obtained from relevant agencies, research reports, literature, journals and other scientific works. Data was validated by triangulation techniques, then the data were analyzed systematically. The results obtained in this study are The social relation between pinggawa and mustard in Kampala Village is to have a close emotional connection and to have a mutually necessary relationship (there is dependency) in their social and cultural life; (2) The highest social structure is Karaeng or those who have a royal lineage who are the holders of power and policy makers; (3) The exploitation that occurs between pheasants and mustard is not in material form, but in the form of the use of power by Karaeng which is carried out for the purpose of popularity, status and political interests to the Karaeng land-use community (the community must follow everything directed by Karaeng).

Keywords: exploitation, power, land resources, pinggawa-sawi 


\section{PENDAHULUAN}

Eksploitasi adalah suatu tindakan untuk memanfaatkan sesuatu secara berlebihan atau sewenang-wenang. Eksploitasi ini bisa menimbulkan kerugian pada lingkungan sekitar atau pada orang lain. Departemen Pendidikan Nasional (1995), eksploitasi merupakan persoalan mendasar dalam berbagai pola-pola hubungan, terutama pola-pola hubungan yang memiliki status sosial ekonomi yang berbeda.Eksploitasi sering diartikan sebagai bentuk pemanfaatan atau pemerasan tenaga orang/manusia untuk keuntungan sendiri atau keuntungan perusahaan.

Salah satu pandangan tentang "eksploitasi" dari James C. Scott dalam hubungan "tuan tanah" dengan "penyewa" kemudian disebut sebagai pola hubungan "patron-klien" yang mengatakan bahwa "Selama hubungan terjadi antara orang-orang yang tidak sama kuat, maka ada kemungkinan hubungan itu berat sebelah. Baik secara perorangan maupun secara kelompok, dimana satu pihak menarik keuntungan atas kerugian pihak lain dan memungkinkan hubungan itu bersifat eksploitasi" (Tantu, 1988 dalam Rakhmat, 2017). Selanjutnya Scott (1972) dalam Rustinsyah (2011) menyatakan bahwa ciri-ciri hubungan patron-klien adalah (1) terdapat suatu ketimpangan (inequality) dalam pertukaran; (2) bersifat tatap muka; (3) bersifat luwes dan meluas.

Sistem eksploitasi juga sangat dekat dalam masyarakat pedesaan yang memiliki stratifikasi sosial didalamnya. Termasuk pada masyarakat di Sulawesi Selatan yang memiliki lembaga atau paling tidak memiliki pola-pola hubungan seperti disebutkan di atas yaitu borjuis-proletar dan patron-klien, pola hubungan tersebut dikenal dengan pola hubungan punggawa-sawi: punggawa adalah penguasa sumberdaya, dan sawi adalah orang yang tidak memiliki sumberdaya kecuali dirinya sendiri (tenaga kerja). Wahyudin, (2003) menyatakan bahwa menurut kebudayaan masyarakat Sulawesi Selatan, jika seseorang memberikan bantuan kepada orang lain, maka akan sangat sulit bagi orang yang menerima bantuan tersebut untuk menentang orang yang telah memberikan bantuan kepadanya. Mekanisme yang diterapkan dari sistem punggawa-sawi adalah pola bagi hasil. Sawi akan menggantungkan hidupnya pada punggawa, selama punggawa tersebut memberikan jaminan sosial melalui pemenuhan kebutuhan hidup sehari-hari keluarga sawi. Selain itu, norma hubungan sosial ini bukan hanya untuk sawi sendiri, melainkan juga diperuntukkan para punggawa agar dapat meningkatkan kesejahteraan para sawi. Tingkat kesejahteraan ini menjadi tolak ukur efektivitas hubungan norma sosial dan seberapa jauh suatu etnis dapat menjamin sumber hidup anggotanya dibandingkan dengan etnis lainnya.

Kecamatan Arungkeke merupakan salah satu wilayah kerajaan dari turunan kerajaan Binamu yang terletak di Kabupaten Jeneponto Provinsi Sulawesi Selatan.Strata sosial tertinggi di daerah tersebut adalah berasal dari turunan raja yang disebut sebagai Karaeng. Seorang Karaeng dalam kehidupan masyarakat Jeneponto sangat unik, dalam arti interaksi sosial dan mempertahankan ciri-ciri pramodern, sebagaimana hubungan pemimpinpengikut, atau borjuis (pemilik modal) dan proletar (tidak memiliki modal), punggawa-sawi yang didasarkan atas sistem kepercayaan. Selanjutnya dalam kajian ini hubungan tersebut dikenal dengan hubungan pinggawa-sawi; pinggawa yaitu penguasa sumberdaya (Karaeng), dan sawi yaitu orang yang tidak memiliki sumberdaya kecuali dirinya sendiri (petani)

Lampe, (2015) menyatakan bahwa melalui analisis internal dan eksternal, fenomena kebertahanan dan dinamika pinggawa-sawi dapat dilacak hingga ratusan tahun ke belakang (backward in time) dan jauh ke luar hingga pusat-pusat pasar ekspor 
(outward in space). Pada satu sisi, koeksistens dan koneksitas mutualis pinggawa-sawi dengan pelaku pasar global dan modernisasi perikanan laut kapitalis (eksternal relation) justru mendorong proses dinamika struktur/relasi pinggawa-sawi (internal relation) dan pada sisi lain, menjamin terjaganya inti-inti struktur/relasi tradisional yang menentukan bagi kekokohannya.

Desa Kampala merupakan salah satu desa di Kecamatan Arungkeke.Masyarakat. Desa Kampala menerima kepemimpinan Karaeng karena mereka mempercayai pemimpin lokal yang memiliki pengaruh kuat dalam budaya lokal. Ketaatan serta harapan masyarakat untuk mendapatkan nilai penghormatan dari Karaeng menjadikan pola kehidupan sosial masyarakat Jeneponto menjadi sangat monolitik namun disisi lain fenomena demikian menjadi sangat berarti bagi Karaeng yang mempunyai kemampuan secara politis/kekuasaan dan materi untuk bisa masuk di ruang publik yang kemudian menjadikan mereka sebagai pemilik dan masyarakat lainnya yang memiliki status sosial dibawah mereka adalah pekerja (Mahendra, 2014).

Berdasar dari hal tersebut, maka perlu dikaji tentang ekspolitasi dan kekuasaan di Desa Kampala Kecamatan Arungkeke Kabupaten Jeneponto dengan melihat penggunaan sumberdaya lahan berdasarkan pendekatan teori sosial Karl Marx.

Penelitian ini bertujuan untuk mengkaji relasi sosial dalam struktur masyarakat lokal di Desa Kampala Kecamatan Arungkeke, serta untuk mengkaji sejauh mana struktur sosial tersebut mencerminkan adanya ekspoitasi kekuasaan pinggawa kepada sawinya.

\section{BAHAN DAN METODE}

\section{Waktu dan Tempat}

Penelitian dilaksanakan di Desa Kampala Kecamatan Arungkeke Kabupaten Jeneponto pada bulan Mei-Juli 2017.

\section{Metode Pengumpulan Data}

Penelitian ini menggunakan pendekatan kualitatif dengan strategi yang digunakan adalah studi kasus. Kasus dalam penelitian ini adalah hubungan antara pinggawa dan sawi di Desa Kampala Kecamatan Arungkeke Kabupaten Jeneponto

Pemilihan lokasi dilakukan secara sengaja (purposive sampling) dengan metode dasar deskriptif analisis.Penentuan informan dengan menggunakan teknik snowball sampling dimana penentuan informan diawali dengan sengaja kemudian berkembang mencari key informan. Jumlah informan yang diwawancarai yaitu 40 orang yang diawali dengan melakukan focuss group discussion. Teknik pengumpulan data menggunakan indepth interview (wawancara mendalam) didukung dengan observasi, pengamatan untuk data primer. Sedangkan data sekunder diperoleh dari instansi terkait, laporan penelitian, literatur, jurnal maupun karya ilmiah lainnya.

\section{Analisis Data}

Data yang didapatkan kemudian dianalisis menggunakan metode kualitatif, untuk memvalidasi data menggunakan teknik triangulasi sesuai pendapat Denzim dan Yvonna (2009) menjelaskan bahwa teknik triangulasi biasanya merujuk pada suatu proses pemanfaatan persepsi yang beragam untuk mengklarifikasi makna, memverifikasi kemungkinan pengulangan dari suatu observasi ataupun interpretasi, namun harus dengan prinsip bahwa tidak ada observasi atau interpretasi yang $100 \%$ dapat diulang. Analisa data dalam kajian ini dilakukan dimulai pada saat memulai kajian dengan mengumpulkan data dan diolah secara sistematis yang dilakukan secara reduksi data dimana data yang diperoleh diseleksi, difokuskan, disederhanakan dan diabstraksikan sesuai catatan lapangan yang didapatkan.Kemudian penyajian data diklasifikasikan sesuai dengan kategori berdasarkan variable yang 
dilihat dan terakhir adalah penarikan kesimpulan atau intrepretasi serta verivikasi data dari hasil penyajian data yang diklasifikasikan. Miles dan Haberman (1991) dalam Sugiyono (2010) menjelaskan bahwa aktivitas data dalam analisis data kualitatif dilakukan secara terus menerus dengan tahap reduksi data, penyajian data dan penarikan kesimpulan.

\section{HASIL DAN PEMBAHASAN}

\section{Relasi Sosial}

Jeneponto adalah salah satu kabupaten yang ada di Sulawesi Selatan lebih dikenal dengan sebutan Turatea.Visi pembangunan Kabupaten Jeneponto Tahun 2013 - 2018 adalah: "Mewujudkan Kepemerintahan yang Baik dan Penguatan Daya saing Daerah Menuju Masyarakat Jeneponto yang Sejahtera. Sedangkan Misi pembangunan adalah: (1) Mewujudkan Tata Kepemerintahan yang Baik, (2) Meningkatkan Kualitas Sumber Daya Manusia; (3) Membangun Kemandirian Ekonomi Masyarakat; (4) Mewujudkan Tata Kelola Keuangan Daerah yang Efektif, Efisien, Produktif, Transparan, dan Akuntabel; (5) Mewujudkan Pembangunan Infrastruktur dan Pelayanan Dasar di setiap Desa/Kelurahan; (6) Meningkatkan Kualitas Kehidupan Beragama.

Secara geografis Kabupaten Jeneponto terletak pada $5^{\circ}$ 23'12" - 5 $5^{\circ} 42^{\prime} 1,2^{\prime \prime}$ Lintang Selatan (LS) dan $119^{\circ} 29^{\prime} 12^{\prime \prime}$ - $119^{\circ} 56^{\prime} 44,9^{\prime \prime}$ Bujur Timur (BT). Letak kabupaten yang pusat pemerintahannya (Kota Bontosunggu) berjarak sekitar $91 \mathrm{~km}$ dari Kota Makassar (Ibukota Provinsi Sulawesi Selatan) tepat berada di Selatan jazirah Pulau Sulawesi. Kabupaten yang secara administratif berbatasan dengan Kabupaten Jeneponto adalah Kabupaten Gowa dan Kabupaten Takalar di sebelah Utara, Kabupaten Bantaeng di sebelah Timur, dan Kabupaten Takalar di sebelah Barat. Untuk bagian Selatan, Wilayah Kabupaten Jeneponto berbatasan langsung dengan Laut Flores. Luas wilayah Kabupaten Jeneponto adalah
$749,79 \mathrm{~km}^{2}$ atau $\pm 1,20 \%$ dari luas wilayah Propinsi Sulawesi Selatan. Secara administratif Kabupaten Jeneponto terbagi atas 11 Kecamatan yang terdiri dari 31 kelurahan dan 82 desa (BPS, 2016).

Salah satu desa yang ada di Kabupaten Jeneponto adalah Desa Kampala yang merupakan salah satu desa di Kecamatan Arungkeke. Luas wilayah Desa Kampala adalah $3,94 \mathrm{~km}^{2}$ atau $13,17 \%$ dari luas wilayah Kecamatan Arungkeke yaitu 29,91 km². Desa Kampala memiliki 4 dusun dan 8 RK yang berada pada daerah pantai. Desa Kampala merupakan desa swakarya yang termasuk desa tertinggal namun kategori berkembang. Jumlah penduduk pada tahun 2016 adalah 2.200 jiwa (1.071 orang lakilaki, dan 1128 orang perempuan) sehingga kepadatan penduduk 558. Sumber mata pencaharian penduduk desa Kampala adalah 17 orang PNS/ABRI, 657 orang TB Mkn, nelayan 26 orang, tambak 8 orang, ternak 6 orang, 68 orang pedagang, industri kecil 21 orang, angkutan 33 orang, dan jasa 26 orang. Untuk luas lahan meliputi; lahan sawah 166,60 Ha, tegalan 159,59 Ha, pekarang 7,70 Ha, lainnya 60,11 Ha (BPS, 2017).

Berdasar dari data di atas, Desa Kampala sebagai salah satu desa di Kecamatan Arungkeke Kabupaten Jeneponto Sulawesi Selatan memiliki potensi kehidupan dalam berbagai aktifitas pertanian.Pada musim hujan masyarakat Arungkeke menggarap sawah-ladang, disamping tambak yang akan menghasilkan produksi sesuai jenis yang diusahakannya, baik berupa bahan pangan (padi dan jagung) maupun ikan. Sedangkan selama berlangsungnya musim kemarau mereka menggarap tambak empang yang diubahnya menjadi ladang-ladang penggaraman, sebagai sumber produksi garam.

Masyarakat Desa Kampala sebenarnya dapat dikategorikan sebagai komunitas yang ulet dan tidak mudah menyerah dengan kondisi alam.Kelompok masyarakat yang memiliki aset berupa tanah sawah, ladang atau ternak 
umumnya tetap bertahan untuk melestarikan hubungan kekerabatan, budaya dan adat (siri' dan sipakatu: menjunjung etika dan silaturahmi). Meskipun begitu, akibat desakan kebutuhan ekonomi, terbatasnya kepemilikan lahan dan faktor produksi lainnya, maka tidak sedikit jumlah penduduk yang terpaksa berurbanisasi ke kota Makassar maupun ke pulau Jawa. Sedangkan yang kurang memiliki keterampilan dan pendidikan terbatas berjuang di sektor informal, transportasi dan konstruksi.Hal ini mengindikasikan bahwa meskipun sektor pertanian masih merupakan sumber penghidupan masyarakat tetapi tumpuan pertumbuhan perekonomian mulai beralih ke sektor non pertanian, namun perkembangannya masih kurang signifikan (Burhanuddin, 2009).

Hubungan kekerabatan masyarakat Desa Kampala terjalin baik namun masih tercermin adanya pola hubungan umumnya yang ada di daerah lain yaitu relasi sosial antara tuan tanah atau pemilik tanah dengan petani penggarap ataupenyewa, petani penyewa dengan buruh tani, petani dengan pedagang, petanidengan pemberi modal, dan lainnya.Relasi sosial di Desa Kampala dalam hal penggunaan sumberdaya lahan dikenal dengan relasi antara pinggawa dan sawi.Hubungan pinggawa-sawi tidak bersifat kaku, melainkan lebih bersifat fleksibel.Hal ini dicerminkan dengan sikap pinggawa yang bisa kapan saja memutuskan hubungan dengan pihak sawi, apabila sawi dianggap tidak lagi mematuhi dan menjalankan aturan-aturan yang telah disepakati.Sebaliknya, sawi pun bisa meninggalkan pinggawa jika pinggawa tersebut tidak mampu memberikan jaminan sosial terhadap kelangsungan hidup keluarga sawi.Akan tetapi, umumnya sawi di Desa Kampala tetap patuh dan taat kepada pinggawa (Karaeng). Hal ini disebabkan oleh karena relasi sosial antara pinggawa dan sawi adalah memiliki hubungan dekat secara emosional dan memiliki hubungan yang saling membutuhkan (ada ketergantungan) dalam kehidupan sosial budayanya.

\section{Struktur Sosial}

Kehidupan masyarakat di Desa Kampala mencerminkan adanya dinamika sosial yang cukup tinggi untuk menjawab tantangan alamnya.Selain itu, adat istiadat yang masih kental dan afiliasi politik yang ada masih didominasi oleh golongan bangsawan atau tuan tanah. Mayoritas pemegang kekuasaan dan pengambil kebijakan adalah Karaeng atau mereka yang memiliki garis keturunan kerajaan yang secara tidak langsung memiliki andil dalam pengupayaan kesejahteraan di masyarakat.Hal ini sejalan dengan yang dinyatakan Hakim (2017) bahwa Arungkeke dikenal sebagai salah satu kerajaan yang berdiri sendiri dan berasal dari turunan Kerajaan Binamu.Secara tradisional pelapisan sosial masyarakat di Arungkeke yang berasal dari tumaradeka (orang merdeka) dibedakan; lapisan pertama ditempati oleh golongan bangsawan (Karaeng), lapisan menengah (Daeng), dan lapisan terendah ditempati golongan bawah (Ata).

Struktur sosial tertinggi masyarakat di Desa Kampala adalah Karaeng.Sekarang ini, Karaeng sebagai lambang status sosial maka siapa yang bisa menguasai arena politik, ekonomi dan sosial secara langsung maupun tidak langsung akan mengangkat dirinya dalam tingkat yang lebih tinggi meskipun seseorang yang awalnya memiliki kelas lebih rendah. Arena pertarungan lapisan sosial sangat dipengaruhi kepemilikan modal, seseorang yang memiliki modal akan mudah beralih status sosial. Sekarang masyarakat Jeneponto termasuk dalam lapisan masyarakat terbuka, sehingga aspek dinamis pun terjadi, perubahan ini nampak dari beberapa golongan ata yang telah berubah status sosial karena pemilikan modal ekonomi dan pengetahuan, walau tidak bisa dipungkiri dominasi para Karaeng tampak masih sangat kuat (Asis, 2017). 
Mirnawati (2017), dalam konteks realitas penggunaan gelar atau sebutan Karaeng dalam kebudayaan Jeneponto di Kecamatan Arungkeke, makna dan penggunaan gelar Karaengsecara verbal dapat dikelompokkan kedalam tiga kategori utama; yaitu karaeng sebagai gelar yang didapatkan (jabatanpemerintahan), karaeng sebagai gelar bangsawan, serta karaeng sebagai sapaanpenghormatan.Pola hubungan/interaksi yang dipengaruhi oleh simbol karaeng dalammasyarakat diantaranya adalah kedudukan sosial (status) dan peranannya, prosessosial masyarakat, dinamika sosial masyarakat, dan keadaan sosial masyarakat.

Kepemimpinan seorang Karaeng dalam kehidupan masyarakat Jeneponto sangat unik, dalam arti interaksi sosial dan mempertahankan ciri-ciri pramodern, sebagaimana hubungan pinggawa-sawiyang didasarkan atas sistem kepercayaan yang sebagaimana diterapkan dalam masyarakat pada umumnya. Masyarakat Jeneponto menerima kepemimpinan Karaeng karena mereka mempercayai pemimpin lokal yang memiliki pengaruh kuat dalam budaya lokal. Ketaatan serta harapan masyarakat untuk mendapatkan nilai penghormatan dari Karaeng menjadikan pola kehidupan politik masyarakat Jeneponto menjadi sangat monolitik namun disisi lain fenomena demikian menjadi sangat berarti bagi Karaeng yang mempunyai kemampuan secara politis untuk bisa masuk di ruang publik. Hal ini menempatkan Karaeng sebagai sebuah strata sosial tertinggi dalam pelapisan masyarakat Jeneponto yang mempunyai posisi yang sangat menentukan struktur politik, ekonomi dan sosial dan menggiring pada terbentuknya politik patrimonial.

Hal ini memiliki kaitan dengan teori kesejahteraan yang dianut Karl Marx. Hakekat kesejahteraan sosial dalam pemikiran Karl Marx adalah apabila suatu masyarakat telah tercipta perwujudan diri melalui kasih sayang, dan kerjasama suatu masyarakat tanpa kelas (classless society), tanpa kekerasan, dan tanpa penindasan, serta manusia yang terbebas dari segala macam bentuk alienasi diri manusia.Kesejahteraan tidak terlepas dari keadilan sosial yang merupakan suatu keadilan yang tergantung pada struktur-struktur kekuasaan yang menguasai golongangolongan yang menderita ketidakadilan (masyarakat tak berdaya terhadap segala macam bentuk kesewenang-wenangan), yang menentukan kehidupan rnasyarakat dalam dimensi politis, ekonomis, sosial, budaya, hukum dan ideologis (Ritzer, G. 2014).

Dalam kehidupan bermasyarakat pelapisan sosial menjadi sesuatu yang niscaya.Umumnya untuk menganalisis lapisan sosial terdapat beberapa dimensi. Dimensi itu antara lain; privilese, kekuasaan dan prestise (Tahara, (2010) dalam Asis, (2017)). Pengelompokan sosial ini merupakan bagian penting dalam menganalisis masyarakat.Kondisi ini memperlihatkan perbedaan pemilikan sumber daya turut memberi pengaruh penting dalam stratifikasi sosial.Perbedaan pemilikan sumberdaya ini kemudian menjadi landasan pembagian lapisan masyarakat secara berlapislapis. Hal ini kemudian menjadikan status sosial dalam lapisan sosial dimasyarakat menjadi sebuah kebanggaan (privilese).

Lapisan sosial mempengaruhi privilese seseorang dimata masyarakat.Semakin tinggi kedudukan seseorang baik secara sosial, ekonomi, maupun politik semakin istimewa kedudukan dan penghormatan seseorang di masyarakat.Di Desa Kampala, hal ini dimiliki oleh seorang Karaeng; kepemilikan modal ekonomi, simbolik dan politik menjadi simbol kebanggaan dan kemudian melahirkan kekuasaan Karaeng kepada masyarakatnya.

\section{Eksploitasi dan Kekuasaan}

Persoalan eksploitasi pada tingkat perorangan atau pada wiraswasta yang bergerak dalam kegiatan pertanian di tingkat pedesaan yang memiliki pola-pola hubungan berdasarkan pada hubungan sosial budaya yang masih kental.Pola-pola hubungan 
para buruh dengan pihak pemberi kerja di tingkat pedesaan yang memiliki adat istiadat yang masih kental, persoalan eksploitasinya tidak gampang mengukur terjadinya eksploitasi. Di tingkat pedesaan antara hubungan kerja dengan hubungan sosial budayanya dalam masyarakat susah dipisahkan. Hubungan kerja, memang tetap pada hubungan batas kerja, tetapi di luar hubungan kerja terjalin pula hubungan sosial budaya yang kuat dan intensif.Secara emosional, antara hubungan kerja dengan hubungan lainnya dalam masyarakat menjadi satu kesatuan kekerabatan. Sehingga pada satu sisi dianggap mengalami eksploitasi, namun pada sisi lain mendapat keuntungan. Sementara terjadinya eksploitasi kerja pada setiap buruh berbedabeda jika pendekatannya pada pelaku (buruh) karena yang merasakan ada tidaknya eksploitasi adalah pelakunya (Rakhmat, 2017).

Pola-pola hubungan yang terjalin dalam usaha penyelenggaraan proses produksi pertanian dan perikanan di Arungkeke, di samping memiliki hubungan kerja antara pemberi kerja dengan pekerja juga memiliki hubungan sosial. Pemberi kerja yang dalam hal ini adalah Karaeng. Rakhmat (2017), pemberi kerja di tingkat pedesaan memang dapat memerankan beberapa tugas, baik sebagai jurutani maupun sebagai manager akan selalu menjalin hubungan kerja dengan beberapa pihak dan biasanya bersifat hirarki. Secara hirarki (James C.Scott, 1989: 54) hubungan kerja tersebut dimungkinkan karena pekerja di satu pihak senantiasa memerlukan lahan. Sementara di lain pihak pemilik adalah penguasa atas lahan. Jaringan kerja antara kedua belah pihak melibatkan diri pada ketentuan hak dan kewajiban yang harus dipenuhi masing-masing demi kelancaran jalanya hubungan kerja.

Hak dan kewajiban antara pekerja dan pemberi kerja yang nampak di Desa Kampala dalam hubungan kerja, di mana hak penggarap yang harus diterima dari pemilik lahan ialah memperoleh lahan sesuai kebutuhan produksi pertanian dan perikanannya. Pola hubungan yang terjalin, apakah sistem bagi hasil; apakah sistem pajak kepada pemilik; atau apakah sistem gadai yang disepakati antara pemiliki dengan penggarap dalam proses kerja sama, tergantung sistem yang mereka sepakati. Demikian pula sebaliknya, pemilik berhak menerima pendapatan dari pihak penggarap atas lahan dan yang telah dimanfaatkan dalam ladang pertanian dan perikanan (hasil wawancara).

Melihat kenyataan seperti itu, nampaknya tidak terjadi hubungan yang bersifat eksploitasi dalam hubungan antara pemilik dengan penggarap sebagaimana analisa James $C$. Scott walaupun secara hirarki berbeda di antara mereka (James C. Scott, 1989 dalam Rakhmat, 2017). Eksploitasi terjadi jika penilaiannya berdasarkan pada perbedaan prosentase keuntungan yang diperoleh pemberi kerja dengan yang diberi kerja.Keuntungan yang diperoleh oleh para pemberi kerja tidak sebanding banyaknya dengan nominal yang diberikan kepada penggarap.Pemberi kerja memperoleh pendapatan yang lebih besar dibanding dengan pekerja.Tetapi perbedaan secara kasat mata belum tentu terjadi eksploitasi. Kondisi di lapangan memperlihatkan kenyataan lain diluar pembagian pendapatan antara pemberi kerja dengan pekerja dalam pertanian dan perikanan di Arungkeke. Ketika kita memperhatikan penggarap di luar kegiatan kerjanya sebagai penggarap dalam proses produksi pertanian dan perikanan, ternyata ada beberapa penggarapyang memiliki hubungan yang lebih intensif dengan pemilik lahan. Hubungan yang intensif yang dimaksud adalah hubungan kekerabatan, dan hubungan sosial budaya lainnya. Pola-pola hubungan yang terlihat disini tidak hanya diikat atas pekerjaan dalam proses produksi pertanian dan perikanan, tetapi juga pekerjaan di luar proses produksi pertanian danperikanan .

Sebagai contoh, jika pemberi kerja memiliki hajatan atau pekerjaan di rumahnya, 
biasanya ia minta bantuan pada penggarap tanpa harus dibayar. Hal ini pula bisa dianggap sebagai bagian dari sistem eksploitasi, tetapi ternyata para penggarap ketika mengalami masalah, ia juga datang ke pinggawanya (pemberi kerja) meminta bantuan. la meminta bantuan bukan hanya satu kali atau dua kali tetapi sering tanpa harus dibayar atau dikembalikan, tetapi dibantu secara cumacuma. Jika bantuan pemberi kerja dinominalkan, maka jumlahnya tidak sedikit dan bahkan keluarga penggarap seperti anak dan istrinya sering makan-minum di rumah pinggawanya/ karaengnya (pemberi kerja).Sehingga para penggarap sebagian besar tidak merasa dieksploitasi oleh pinggawanya.Walaupun juga harus diakui bahwa ada juga pengakuan dari pengarap yang merasa dieksploitasi oleh pinggawanya (Hasil wawancara).

Ketika penggarap yang dinilai dieksploitasi oleh para pemberi kerja ditanya, apakah merasa dieksploitasi oleh pinggawanya atau tidak?.Mereka (penggarap) menjawab tidak merasa dieksploitasi karena mereka lakukan atas dasar kerelaan dan keiklasan (Hasil wawancara).Bahkan penggarap merasa bersyukur atas pekerjaan itu dan mendapat pinggawa seperti pinggawanya yang banyak membantunya ketika mendapat kesulitan tanpa dipotong gajinya.Kenyataan ini terjadi karena kuatnya pengaruh kultural terhadap sistemsistem budaya yang ada didalamnya.

Kepemilikan lahan yang ada di Jeneponto umumnya sama dengan daerah lainnya. Untuk lahan yang ada di Arungkeke yang ditempati oleh masyarakat Desa Kampala adalah $90 \%$ lahan adalah milik Karaeng $( \pm 800$ Kepala Keluarga).Status lahan itu adalah hak guna yang diberikan oleh Karaeng untuk dimanfaatkan dalam kehidupan warganya. Secara umum penggunaan lahan di Jeneponto yang memiliki nilai ekonomi, sistem pembagian hasilnya adalah masing-masing 50\% hak pengguna dan $50 \%$ hak pemilik. Selain itu, ada juga hak pemilik memberikan sepenuhnya hasil untuk digunakan pengguna lahan.Serta ada pula sistem pembagian hasil dimana pengguna lahan saat panen hanya memberikan seadanya kepada pemilik lahan (tidak ada kesepakatan).Sistem bagi hasil di Desa Kampala adalah pengguna (petani) memberikan seadanya ke pemilik (Karaeng).

Berdasar dari hal tersebut, pengguna lahan memiliki hubungan emosional yang kuat dengan pemilik lahan yaitu, pengguna lahan mengikuti semua keputusan yang sudah ditetapkan oleh pemilik lahan (Karaeng).Hal ini erat hubungannya dengan pemerintahan yang ada.Sistem kepemimpinan yang ada di Arungkeke sepenuhnya dikuasai oleh dinasti Karaeng, dimana masyarakat yang ada secara umum mengikut keputusan oleh pemimpin (Karaeng).Demikian halnya dengan kepentingan politis (pengambilan keputusan/suara bulat berdasarkan keputusan Karaeng). Karaeng dalam kepemimpinannya memperlakukan masyarakat secara merata (sama), seperti pembagian bantuan dari pemerintah baik infrastruktur maupun penggunaan alat pertanian yang digunakan secara bersama.

Pola hubungan pinggawa-sawi merupakan salah satu bentuk pola hubungan yang tidak sama kuat atau tidak seimbang. Sebab pinggawa adalah pemilik modal atau penguasa faktor produksi dalam suatu perusahaan atau dalam sistem pertanian.Sementara sawi adalah pengikut atau anak buah dalam suatu sistem kerja pada suatu perusahaan atau dalam sistem kerja yang dipimpin atau yang dimiliki oleh pinggawa.Sawi juga sering disamakan dengan buruh, walaupun dalam hal-hal tertentu memiliki perbedaaan.Jika sawi terikat dalam hubungan dekat secara emosional dan memiliki hubungan yang saling membutuhkan (ada ketergantungan) dalam kehidupan sosial budayanya maka sawi tidak bisa disamakan dengan buruh pada umumnya tetapi lebih kepada pengikut.Sementara sawi sebagai buruh adalah sawi yang memiliki hubungan dan 
terbatas pada sistem kerja semata.Tetapi dalam pengistilahan kegiatan kerja pada masyarakat Jeneponto sering dicampurbaurkan.Pola-pola hubungan yang tidak seimbang tersebut banyak bentuknya di dalam masyarakat Jeneponto tetapi apakah didalamnya terjadi eksploitasi atau tidak.Hal itu perlu pengkajian secara khusus karena hubungan pinggawa-sawi pada setiap sistem kerja yang melibatkan pinggawa-sawi tidak selamanya terjadi eksploitasi.

Berdasarkan hasil kajian yang telah dilakukan. Di Desa Kampala Kecamatan Arungkeke Kabupaten Jeneponto, hubungan sosial antara pinggawa-sawi adalah simbiosis mutualisme, yaitu hubungan saling membutuhkan. Pinggawa membutuhkan sawi untuk memproduksi barang, sawi pun membutuhkan pinggawa untuk mendapatkan gaji dalam menghidupi keluarganya. Karaeng dalam memperlakukan masyarakatnya sama tanpa adanya kelas sosial, sehingga tidak banyak terjadi konflik antar keduanya. Hubungan ini sesuai standar serta kualitas dan kuantitas pekerjaan masing-masing.

Dalam kehidupan sehari-hari, kekuasaan pinggawa atas sawi di Desa Kampala adalah jelas terlihat pada kuatnya pengaruh dalam segala hal (khususnya terkait politik). Contoh, jika dilakukan suatu pemilihan yang membutuhkan suara Rakyat, maka pinggawa (Karaeng) memiliki kekuasaan penuh kepada sawi (warganya) untuk mengikuti apa yang diinstruksikan Karaeng untuk dipilih. Apabila ada yang melanggar maka sanksi akan diberikan dengan pencabutan hak penggunaan lahan serta tidak mendapatkan bantuan apapun dari Karaeng maupun pemerintah setempat. Hal ini sesuai dengan penyataan Windhu, (1992) bahwa dalam kehidupan sehari-hari, bentuk-bentuk kekuasaan tampak dalam pengaruh, kharisma, kepemimpinan atau wewenang, kekuasan merupakan bagian setiap orang, entah sebagai orang tua, guru, buruh, warga negara, tetangga, rakyat, ataupun Presiden. Kekuasaan selalu ada dimana-mana, kekuasaan hadir disaat manusia melakukan interaksi sosial dengan sesama.

Kekuasaan Karaeng di Desa Kampala Kecamatan Arungkeke Kabupaten Jeneponto adalah kekuasaan yang bersumber dari kekuasan yang diperoleh karena pembawaan sejak lahir (keturunan raja).Selain itu, Karaeng juga memiliki sumber-sumber kemakmuran berupa lahan pertanian dan perikanan yang luas.Hal ini sesuai dengan yang dinyatakan Windhu, (1992) bahwa tiga sumber kekuasaan yaitu; Pertama, kekuasaan yang diperoleh karena pembawaan sejak lahir, seperti seorang raja yang kharismatik. Kedua, kekuasaan yang diperoleh karena memiliki sumber-sumber kemakmuran, seperti kekayaan alam yang dimiliki. Dan ketiga, kekuasaan yang diperoleh karena kedudukannya dalam suatu struktur, seperti halnya seorang presiden.Hal ini juga sejalan dengan pernyataan Pranata, (2012) bahwa bentuk kekuasaan pada masyarakatmasyarakat tertentu di dunia ini beraneka macam dengan masing-masing polanya.Salah satu tipe bentuk kekuasaan adalah tipe kasta, yaitu sitem lapisan kekuasaan dengan garis pemisah yang tegas dan baku, biasanya dijumpai pada masyarakat berkasta.

\section{KESIMPULAN}

Hasil penelitian ini menunjukkan bahwa relasi sosial antara pinggawa dan sawi adalah memiliki hubungan dekat secara emosional dan memiliki hubungan yang saling membutuhkan (ada ketergantungan) dalam kehidupan sosial budayanya dengan struktur sosial tertinggi adalah Karaeng atau mereka yang memiliki garis keturunan kerajaan yang menjadi pemegang kekuasaan dan pengambil kebijakan. Sehingga ekspolitasi yang terjadi antara pinggawa dan sawi tidak dalam bentuk materi, akan tetapi dalam bentuk penggunaan kekuasaan oleh Karaeng yang dilakukan untuk tujuan popularitas, status maupun kepentingan politik kepada masyarakat pengguna lahan Karaeng. Masyarakat wajib mengikuti semua 
yang diarahkan oleh Karaeng (patuh kepada Karaeng).

\section{UCAPAN TERIMA KASIH}

Terima kasih diucapkan kepada Pemerintah Daerah Kabupaten Jeneponto khususnya Pemerintah Desa Kampala Kecamatan Arungkeke yang telah bersinergi dalam pelaksanaan penelitian ini sehingga penelitian ini dapat terlaksana dengan baik.

\section{DAFTAR PUSTAKA}

Ansgari, I. 2006. Dampak Perilaku Eksploitasi Terhadap Efisiensi dan Tingkat Kehidupan Petani Plasma PIR-SUS Kelapa Sawit.Jurnal Ekonomi Pembangunan Vol. 4 No. 2/2006: 61-72.

Asis, P.H. 2017. Jeneponto: Masyarakat dan Kebudayaannya.

(www.academia.edu/21452792/jenepont o masyarakat dan kebudayaan). Diakses pada tanggal 29 Juli 2017.

Beilharz, P. (2016). Teori-teori Sosial. Pustaka Pelajar, Yogyakarta.

BPS. 2016. Kabupaten Jeneponto dalam Angka 2016. Badan Pusat Statistik Kabupaten Jeneponto, Jeneponto.

2015. Indikator Kesejahteraan Rakyat 2015. Badan Pusat Statistik Kabupaten Jeneponto, Jeneponto.

2017.Kecamatan Arungkeke dalam Angka 2017.Badan Pusat Statistik Kabupaten Jeneponto, Jeneponto.

Burhanuddin, R. 2006. Pemberdayaan Petani Miskin di Kabupaten Jeneponto Provinsi Sulawesi Selatan. Jurnal Fakultas Ekonomi Universitas Tarumanagara, Jakarta.

Demmallino, E.B., 2017. Siratal Mustakim: Kajian dan Gagasan Transformasi Peradaban Kemaritiman di Negeri Bugis-Makassar Sulawesi Selatan. Makassar.

Denzim, N.K., Yvonna, S.L. 2009. Handbook of Qualitative Research. Pustaka Pelajar, Yogyakarta.

Departemen Pendidikan Nasional. 2015. Kamus Besar Bahasa Indonesia. Departemen Pendidikan Nasional, Jakarta.
Hakim, M. 2017.Resistance of Women "Karaeng" Culture in Marriage: A Case Study of The District Community Bangkala Jeneponto Indonesia. European Journal Research in Social Sciences. Vo. 5. 2017.

Hernawan, A. 2011. Hukum dan Kekuasaan dalam Hubungan Industrial.Mimbar Hukum Edisi Khusus, November 2011, Halaman 1-237

Lampe, M. 2015. Pinggawa-Sawi Nelayan Bugis-Makassar dalam Analisis Relasi Internal dan Ekstrenal.Jurnal Masyarakat dan Budaya, Volume 17 No.I Tahun2015.

Mahendra, A. 2014.Budaya Politik Patrimonialisme dalam Pemilihan Kepala Daerah di Kabupaten Jeneponto. Skripsi Universitas Hasanuddin, Makassar.

Mahmuda, E. dan Sugeng, H. 2014. Bargaining Position Petani dalam Menghadapi Tengkulak Jurnal Paradigma Volume 02 Nomor 01 Tahun 2014.

Maliki, M. 2013. Buruh, Eksploitasi, dan Kesenjangan Kelas Ditinjau dalam Perspektif Marxisme. Universitas Al Azhar Indonesia, Jakarta.

Mirnawati. 2017. Simbol Karaeng Bagi Masyarakat Jeneponto(Kasus di Desa Bulo-Bulo Kecamatan Arungkeke Kabupaten Jeneponto). Skripsi Departemen Sosiologi Fakultas IImu Sosial dan IImu Politik UniversitasHasanuddin, Makassar.

Mustafa, M.D. dan Andi, AA. 2017. Kajian Struktur Sosial Kelompok Nelayan Ikan Terbang di Kabupaten Takalar. Jurnal Perikanan dan Kelautan Volume 7 Nomor 1. Juni 2017 Halaman: 71-81.

Pranata, R. 2012. Pengertian dan Latar Belakang Teori Kekuasaan Menurut Para Ahli.

(http://pengabdianqu.blogspot.co.id/2012 /06/pengertian-dan-latar-belakangtoeri.html. Diakses pada tanggal 13 Oktober 2017.

Rakhmat, MA. 2017. Persoalan Eksploitasi Buruh dalam Pola-pola Hubungan dalam Pertanian Garam di Arungkeke.Badan Nasional Penanggulangan Bencana Sulawesi Selatan, Makassar. 
Ritzer, G. 2014.Teori Sosiologi: Dari Sosiologi Klasik Sampai Perkembangan Terakhir Postmodern. Edisi kedepan 2012.Pustaka Pelajar, Yogyakarta.

Rustinsyah. 2011. Hubungan Patron-Klien di Kalangan Petani Desa Kebonrejo.Jurnal Departemen Antropologi FISIP Universitas Airlangga. Volume 24 Nomor 2 Hal: 176-182, Surabaya.

Sugiyono.2010. Metode Penelitian Kuantitatif, Kualitatif, dan R\&D. Alfabeta, Bandung.

Syamsurianto. 2015. Konflik antar Pengusaha dan BUruh Menurut Karl Marx. (www.kompasiana.com). Diakses pada tanggal 10 Agustus 2017.

Wahyudin, Y. 2003. Sistem Sosial Ekonomi dan Budaya Masyarakat Pesisi.Pusat Kajian Sumberdaya Pesisir dan Lautan. Institut Pertanian Bogor, Bogor.

Windhu, I.M. 1992. Kekuasaan dan Kekerasan Menurut Johan Galtung. Kanisius, Yogyakarta. 